\title{
Neurofibromatosis type I: points to be considered by general pediatricians
}

\author{
Eungu Kang, MD, PhD ${ }^{1}$, Hee Mang Yoon, MD, $\mathrm{PhD}^{2}$, Beom Hee Lee, MD, $\mathrm{PhD}^{3}$ \\ ${ }^{1}$ Department of Pediatrics, Korea University Ansan Hospital, Korea University College of Medicine, Ansan, Korea; ${ }^{2}$ Department of Radiology, Asan Medical Center, \\ University of Ulsan College of Medicine, Seoul, Korea; ${ }^{3}$ Department of Pediatrics, Asan Medical Center, University of Ulsan College of Medicine, Seoul, Korea
}

Neurofibromatosis type 1 (NF1), a prevalent genetic disease that is transmitted in an autosomal dominant manner, is characterized by multiple cutaneous café-au-lait spots and neurofibromas as well as various degrees of neurological, skeletal, and neoplastic manifestations. The clinical features of NF1 increase in frequency with age, while the clinical diagnosis can remain undetermined in some pediatric patients. Importantly, affected patients are at risk for developing tumors of the central and peripheral nervous system. Therefore, adequate counseling for genetic testing, age-appropriate surveillance, and management are important. This review suggests several issues that should be considered to help general pediatricians provide adequate clinical care and genetic counseling to patients with NF1 and their families.

Key words: Neurofibromatosis type 1, NF1, Diagnosis, Surveillance, Treatment

\section{Key message}

- The spectrum of neurofibromatosis type I (NF1) includes tumors and cutaneous, ocular, neurological, musculoskeletal, vascular, and cardiac manifestations.

- The wide phenotypic heterogeneity renders the diagnosis of NF1 difficult in some patients. Genetic tests provide important information regarding the diagnosis and prognosis and future reproductive options for family members.

- As the NF1 spectrum evolves with age, surveillance of its clinical features must be age-appropriate and management adequate.

\section{Introduction}

Neurofibromatosis type 1 (NF1; OMIM\#162200) is a prevalent genetic disease that affects 1 in 3,000 individuals. NF1 is transmitted in an autosomal dominant manner and characterized by multiple cutaneous café-au-lait spots and neurofibromas. Variable degree of neurological, skeletal, and neoplastic manifestations are also noted. Affected patients are at risk of developing tumors of the central and peripheral nervous systems. ${ }^{1,2)}$

The phenotypes of several genetic diseases, especially those with autosomal dominant inheritance, are widely heterogeneous because of the differences in penetrance and expressivity among patients. NF1 is a genetic disorder with high penetrance, and almost all affected persons have café-au-lait spots; however, the extent of cutaneous lesions is highly variable among patients, e.g., its range of expressivity is wide. ${ }^{3)}$

Such phenotypic heterogeneity renders NF1 difficult to diagnose. In such situations, genetic tests provide important information about its diagnosis and prognosis as well as future reproductive options for family members. Age-appropriate surveillance and management are important to improving the quality of life of affected patients.

This review suggests several points from the clinical and molecular genetic perspectives to help general pediatricians provide adequate clinical care and genetic counseling to patients with NF1 and their families.

\section{Diagnosis of neurofibromatosis type I}

A diagnosis of NF1 is based on National Institutes of Health (NIH) criteria. ${ }^{4)}$ The important clinical features of its diagnosis include the size and number of café-au-lait spots and freckling, cutaneous neurofibromas, Lisch nodules in the eyes, and family history. However, some patients do not meet the NIH criteria for diagnosis; for example, some pediatric patients have only a few café-au-lait spots of variable size. By the age of 1 year, only about $50 \%$ of infants without a family history of NF1 will meet these criteria. $^{5)}$

Because the frequency of clinical NF1 features increases with age, a clinical diagnosis cannot always be determined in pediatric patients. Overt NF1 manifestations such as optic pathway glioma and skeletal dysplasias, such as sphenoid dysplasia or tibial pseudarthrosis, can help confirm a diagnosis in such pati-

\footnotetext{
Corresponding author: Beom Hee Lee, MD, PhD. Department of Pediatrics, Asan Medical Center Children's Hospital, University of Ulsan, College of Medicine, 88, Olympicro 43-Gil, Songpa-gu, Seoul 05505, Korea 
ents. Other clinical features suggestive of NF1 include macrocephaly and areas of focal abnormal signal intensity (FASI) in the brain, which have been detected in $59.5 \%$ and $87.0 \%$ of Korean pediatric patients aged $<8$ years with NF1, respectively. ${ }^{3)}$

Genetic tests can help confirm the diagnosis of NF1. Only the NF1 gene, which contains 57 constitutive exons and at least 3 alternatively spliced exons, is responsible for NF1. It is a large gene with highly homologous NF1 pseudogenes that interfere with genetic tests. The direct sequencing of genomic DNA alone has a detection rate of $\sim 60 \%$ in patients with NF1. ${ }^{6,7)}$ Therefore, multistep analyses of genomic and complementary DNA and changes in exon copy numbers have been recommended as standard tests, and their mutation detection rate is $95 \%$ among patients with NF1. ${ }^{8-10)}$ However, these methods are laborintensive; thus, we developed long-range polymerase chain reaction (PCR) and multiplex ligation-dependent probe amplification analyses of genomic DNA and identified NF1 mutations in $87.1 \%$ of 389 Korean families. ${ }^{3)}$

Still, a subset of patients with NF1 has no known NF1 mutations but might have germline mutations in the regulatory or splicing regions of the NF1 gene or somatic mosaic NF1 genetic mutations. Conventional PCR and sequencing techniques might overlook these mutations because their mutation burden is low; moreover, these techniques are mostly qualitative and not quantitative.

Another point to consider in diagnosis workups is that patients could be affected by other genetic diseases such as Legius syndrome (OMIM\#611431), a constitutional mismatch repair deficiency (OMIM\#276300), NF II (OMIM\#101000), Noonan syndrome with multiple lentigines (OMIM\#151100), multiple café-au-lait spots (OMIM\#114030), and partial unilateral lentinogenesis. Some patients with these disorders might meet the diagnostic criteria of NF1. However, Lisch nodules and cutaneous or internal neurofibromas are not associated with any of these conditions. Nonetheless, NF1 is a lifelong evolving disease, and pediatric patients might not manifest its full spectrum. Therefore, a molecular differential diagnosis can help. The use of magnetic resonance imaging to identify brain areas with FASI also helps in the diagnosis.

Approximately $8 \%$ of pediatric patients with café-au-lait spots but no other clinical features of NF1 might have Legius syndrome, which is caused by a heterozygous mutation in the SPRED1 gene that enhances Ras inactivation by interacting with neurofibromin and translocates neurofibromin from the cytosol to membrane-anchored Ras. ${ }^{11)}$ Therefore, genetic testing for the SPRED1 gene can be considered for patients with café-au-lait spots but no NF1 gene mutations. A small subset of patients has café-au-lait spots but no mutations in the NF1 gene or any other genes responsible for the related genetic diseases. Multiple caféau-lait spots (OMIM\#114030) can be inherited in an autosomal dominant manner. Whether this benign condition is a separate genetic disease remains to be determined, and a genetic cause has not been identified.

\section{Value of genetic diagnosis}

NF1 can be diagnosed based on the NIH criteria without genetic testing. Thus, patients or their family members might question physicians about the value of genetic testing for NF1.

Counseling is critically important during the process of genetic testing for NF1. Pretest counseling should include informing patients and/or their parents that mutation detection rates differ among test methods and that negative results do not necessarily exclude NF1. The identification of a pathogenic mutation provides important information than can predict the natural course of the disease. For example, a whole NF1 gene deletion or a haploinsufficient NF1 gene is associated with the early manifestation of neurofibromas, more frequent and severe intellectual disabilities, and dysmorphic facial features, ${ }^{11,12)}$ and a 3-bp inframe deletion in exon 17 (c.2970-2972delAAT) is associated with a milder NF1 phenotype without cutaneous neurofibromas. ${ }^{13)}$ Missense variants at Arg1809 are associated with multiple café-au-lait spots and Noonan syndrome-like features. ${ }^{14,15)}$ Moreover, plexiform neurofibromas (PN), symptomatic spinal neurofibromas, optic pathway gliomas, and skeletal abnormalities are more frequently seen in patients with a missense mutation at codons 844-848. ${ }^{16)}$ However, besides these correlations between specific genotypes and phenotypes, the overall genotype-phenotype correlations in NF1 have remained elusive. We recently classified overall correlations in a large cohort of Korean patients with NF1. ${ }^{3)}$ Severe NF1 phenotypes were classified as being in a distinct or "NF1-plus" $\left(\mathrm{NF} 1^{+}\right)$ subgroup. The features of this group comprise manifestations considered clinically severe and requiring medical attention. Such manifestations include widespread diffuse cutaneous neurofibromas, learning disabilities, autism, seizures, cardiac abnormalities, hearing defects, optic pathway gliomas, severe PN ( $>3 \mathrm{~cm}$ in diameter) accompanied by disfigurement, pain, bony destruction, or located in the para-aortic area, brain tumors, nerve root tumors, malignant peripheral nerve sheath tumors, moyamoya disease, and bony dysplasia.

This subclassification led to the detection of a higher prevalence of $\mathrm{NF}^{+}$in patients with disruptive NF1 mutations including NF1 haploinsufficiency; frameshift, nonsense, and splicing mutations; and a lower prevalence in patients with missense/inframe NF1 mutations (64.3\% in large deletions, $59.6 \%$ in truncating/splicing mutations, and $36.6 \%$ in missense/ inframe mutations, $P=0.001){ }^{3}{ }^{3)}$ These findings provided im. portant information in terms of genetic counseling for families as well as patients with NF1. As NF1 is mostly diagnosed in children, parents are concerned about their child's long-term prognosis. Because NF1 is a lifelong evolving disease, the natural outcomes of affected patients are difficult to predict based on the clinical features evaluated at the time of diagnosis. In these settings, knowledge of the genotype responsible for NF1 in individual patients might help predict the severity of their natural clinical course. However, although NF1 is a highly penetrant autosomal dominant disease, the phenotypic expressivity is wide 
among patients and even within family members with the same genotype.

Another benefit of genetic diagnosis is the availability of reproductive options for the affected patients or their family members. Approximately 50\% of patients with NF1 have no known family history of NF1, ${ }^{5}$ and $70 \%$ of NF1 cases in Korean patients are sporadic. ${ }^{3)}$ Prenatal genetic tests can be considered for the parents of a child with sporadic NF1 who wish to have more children in the future since germline mosaicism remains possible in either parent. Prenatal genetic tests or a preimplantation genetic diagnosis can be considered if an adult patient with NF1 plans a pregnancy because the risk of NF1 transmission from either parent to the baby is 50\%. Families with a confirmed pathogenic NF1 mutation can choose to undergo prenatal tests and preimplantation genetic diagnoses. Prenatal tests to be considered are chorionic villi sampling and amniocentesis or cord blood sampling during gestational weeks 10-13, 15-20, and 20-
24, respectively. A preimplantation diagnosis can be achieved by genetic tests to identify a pathogenic NF1 mutation of concern in one or more cells removed from early embryos conceived by in vitro fertilization, followed by the transfer of embryo(s) without the mutation to the uterus.

\section{Age-appropriate surveillance}

Because of the wide phenotypic NF1 heterogeneity and the fact that the NF1 spectrum evolves with age, the surveillance of clinical features must be age-appropriate. The spectrum of NF1 includes cutaneous, ocular, neurological, musculoskeletal, vascular and cardiac manifestations, and tumors (Table 1). 1,2,17-26) Cutaneous symptoms including café-au-lait spots are common in pediatric patients, whereas cutaneous neurofibromas are not. Lisch nodules are melanocytic iris hamartomas, which are detectable in only $50 \%$ of pediatric patients and in $\sim 75 \%$ of

Table 1. Clinical features of neurofibromatosis type I and the health supervision guideline recommended by the American Academy of Pediatrics

\begin{tabular}{|c|c|c|}
\hline Clinical manifestation & Frequency (\%) & Health supervision guidelines ${ }^{11}$ \\
\hline $\begin{array}{l}\text { Cutaneous } \\
\text { Multiple café-au-lait spots } \\
\text { Intertriginous freckling } \\
\text { Juvenile xanthogranuloma }\end{array}$ & $\begin{array}{l}100 \% \\
90 \% \\
\sim 10 \%\end{array}$ & $\begin{array}{l}\text { Skin examination - at least annually from early childhood } \\
\text { to adulthood }\end{array}$ \\
\hline $\begin{array}{l}\text { Ophthalmologic } \\
\text { Lisch nodules } \\
\text { Retinal vasoproliferative tumors } \\
\text { Neovascular glaucoma } \\
\text { Myopia }\end{array}$ & $\begin{array}{l}\quad>80 \% \\
\text { Infrequent } \\
\text { Infrequent } \\
\text { Infrequent }\end{array}$ & $\begin{array}{l}\text { Ophthalmoligic examination - at least annually from } \\
\text { infancy to puberty }\end{array}$ \\
\hline $\begin{array}{l}\text { Neurological } \\
\text { Learning disabilities or behavioral problems } \\
\text { Frank intellectual disability } \\
\text { Autism spectrum disorder } \\
\text { Polyneuropathy } \\
\text { Seizures } \\
\text { Sleep disturbance } \\
\text { Migraine headaches }\end{array}$ & $\begin{array}{c}\sim 50 \%-80 \% \\
6 \%-7 \% \\
\sim 30 \% \\
\sim 10 \% \\
5 \%-29 \% \\
\sim 10 \%-50 \% \\
\sim 50 \%\end{array}$ & $\begin{array}{l}\text { Neurologic examination - at least annually from early } \\
\text { childhood to adulthood }\end{array}$ \\
\hline $\begin{array}{l}\text { Vascular } \\
\text { Hypertension } \\
\text { NF1 vasculopathy } \\
\text { Renal artery stenosis } \\
\text { Coarctation of the aorta, and other vascular lesions } \\
\text { Moyamoya }\end{array}$ & $\begin{array}{l}5 \%-29 \% \\
5 \%-29 \%\end{array}$ & $\begin{array}{l}\text { Monitor blood pressure at least annually from early } \\
\text { childhood to adulthood. } \\
\text { Diagnostic image examinations are mandatory for } \\
\text { significant abnormalities and/or new signs }\end{array}$ \\
\hline $\begin{array}{l}\text { Tumors } \\
\text { Cutaneous neurofibromas } \\
\text { Plexiform neurofibromas } \\
\text { Malignant peripheral nerve sheath tumors } \\
\text { Optic nerve gliomas } \\
\text { Brain tumors } \\
\text { Leukemia } \\
\text { Gastrointestinal stromal tumors }\end{array}$ & $\begin{array}{c}100 \% \\
\sim 20 \%-30 \% \\
5 \% \\
\sim 15 \% \\
\text { Rare } \\
\text { Rare } \\
\text { Rare }\end{array}$ & $\begin{array}{l}\text { Skin examination - at least annual from early childhood } \\
\text { to adulthood. } \\
\text { Diagnostic image examinations are mandatory for } \\
\text { significant abnormalities and/or new signs }\end{array}$ \\
\hline
\end{tabular}

NF1, neurofibromatosis type 1.

Adapted from Miller DT, et al. Pediatrics 2019;143:e20190660.1) 


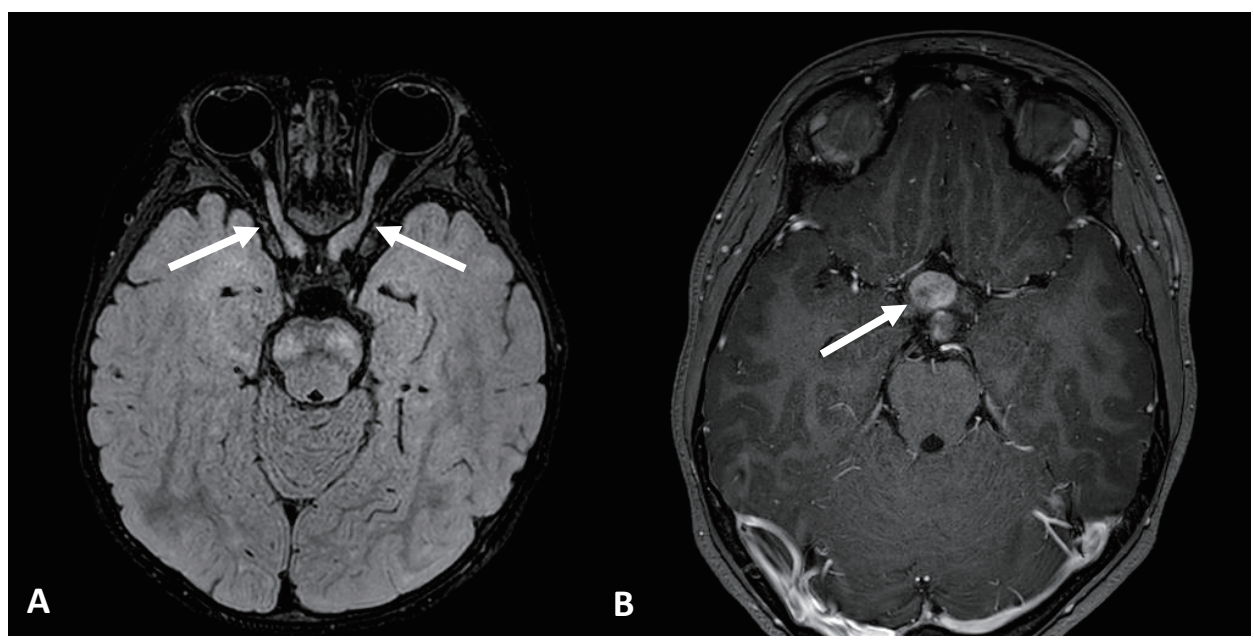

Fig. 1. Axial brain magnetic resonance images of optic pathway glioma in neurofibromatosis type 1. (A) Two-year-old girl with thickening and tortuosity involving the bilateral optic nerves (arrows) with slightly increased signal intensity on a fluid attenuation inversion recovery image. (B) Eight-year-old girl with masslike thickening involving the optic chiasm (arrow) with heterogeneous enhancement on a contrast-enhanced T1-weighted image.

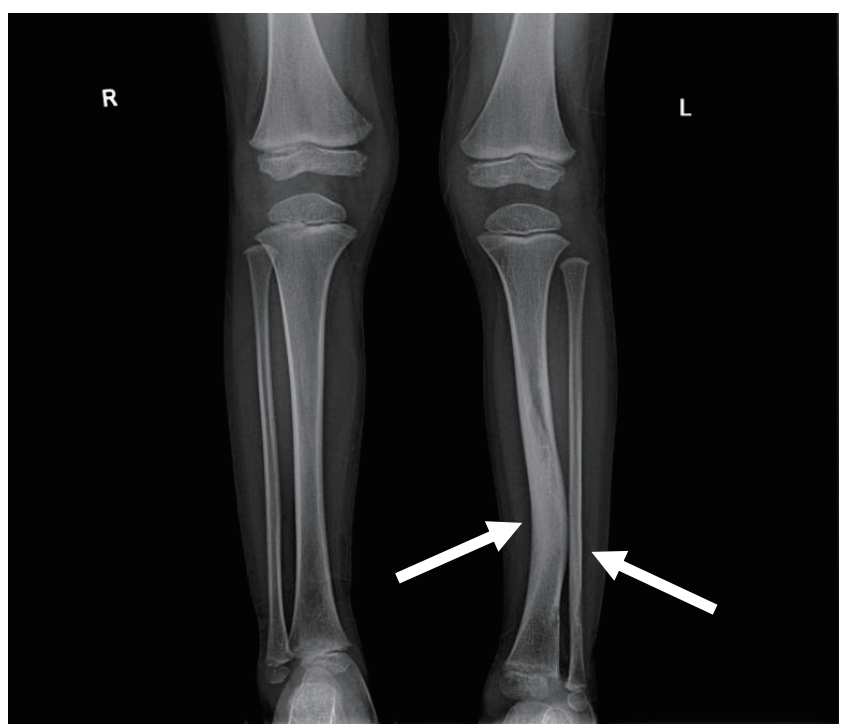

Fig. 2. Simple x-ray image of a 5-year-old boy with neurofibromatosis type 1. Anterolateral bowing deformity of the left distal tibia and sclerotic change in the distal shafts of the left tibia and fibula (arrows).

mid-teen patients. ${ }^{22)}$ Optic pathway gliomas are the most important ocular findings in pediatric patients (Fig. 1) because although most are asymptomatic, their progression can lead to a loss of visual acuity, proptosis, and strabismus.

Gross motor development is frequently delayed, and learning disabilities, intellectual deficits, and autism spectrum disorder might be encountered. Although seizures are infrequently encountered, the rates are higher in patients with NF1 than in the general population. Most individuals with NF1 have normal intelligence. However, learning deficits or behavioral problems and attention deficits are evident in 50\%-80\% of affected patients. ${ }^{27,28)}$

Osteopenia with vitamin D deficiency is another frequent manifestation, and skeletal dysplasia usually affects the sphenoid bones, lower legs, and vertebrae (Fig. 2). Scoliosis is also more

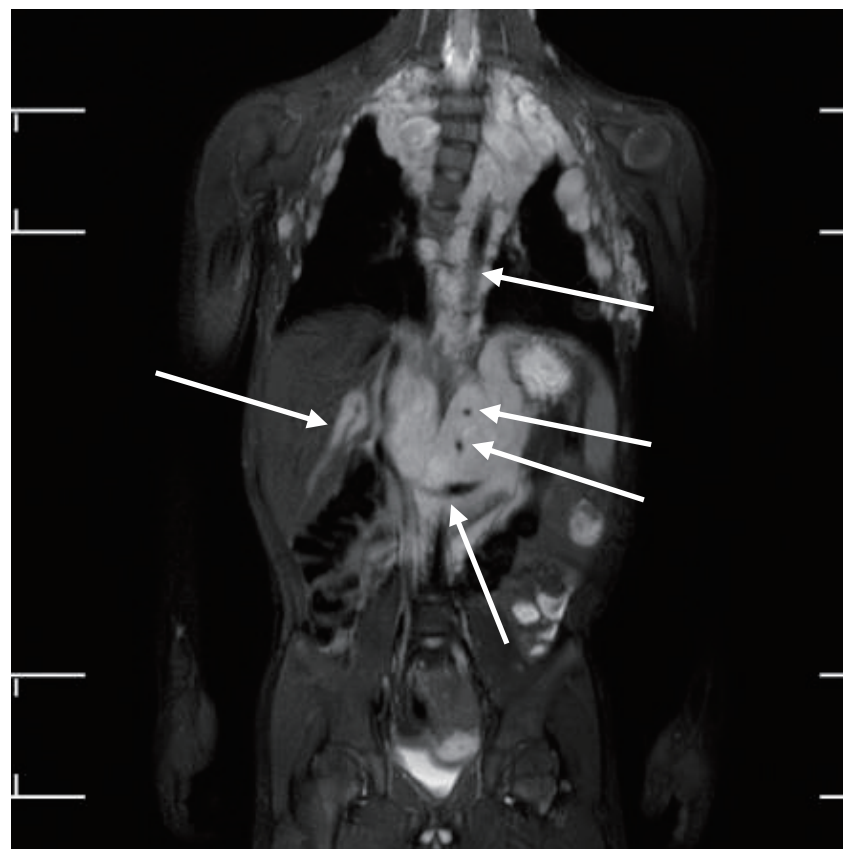

Fig. 3. Whole-body magnetic resonance images of a 5-year-old boy with neurofibromatosis type 1 . There are extensive plexiform neurofibromas involving the thoracic paravertebral regions, intercostal spaces, anterolateral chest wall, retrocrural space, and upper abdominal retroperitoneum. The aorta and its branches (celiac trunk and superior mesenteric artery), left renal vein, and intrahepatic portal vein are encased by the plexiform (arrows). Thoracic scoliosis with right-sided convexity is noted.

prevalent in NF1 than in the general population, and stenotic or ectatic vascular abnormalities can also emerge. Moyamoya disease is 3-fold more prevalent in children with NF1 than in the general population. ${ }^{25)}$ In addition, renal artery stenosis and arterial aneurysms can occur. The pathogenesis of NF1-related vasculopathy is poorly understood; however, impaired neurofibromin expression in vascular endothelial cells is likely to result in abnormal vascular proliferation and growth. ${ }^{29)}$ 


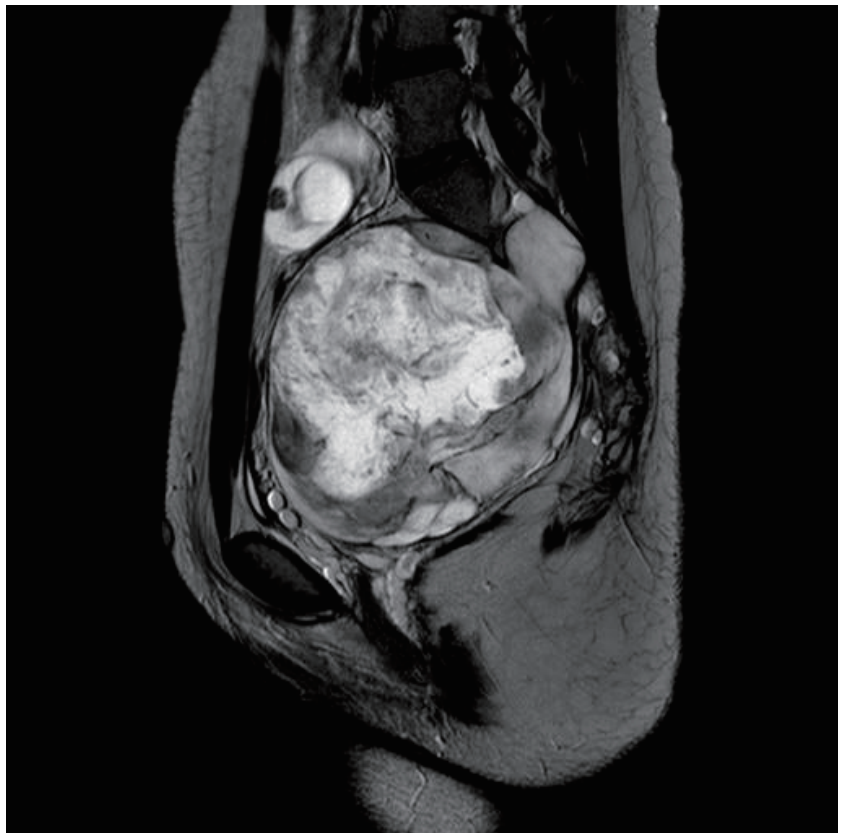

Fig. 4. Pelvic magnetic resonance image of a 15-year-old girl with neurofibromatosis type 1 . A huge lobulating malignant peripheral nerve sheath tumor is located at presacral area of the pelvic cavity along the right S2 nerve root extending to the right S2-3 foramen and spinal canal.
Tumors are the most critical complications of NF1. Cutaneous neurofibromas are benign, and their surgical removal can be recommended for selected patients. Patients with NF1 are at risk of developing tumors of the central and peripheral nervous systems, including PN (20\%-30\%), optic gliomas ( 15\%), pheochromocytomas (1\%), and malignant peripheral nerve sheath tumors (5\%) (Fig. 3). ${ }^{1,2)} \mathrm{PN}$ are benign nerve sheath tumors that result in devastating complications of NF1. They are thought to be congenital but might not be diagnosed until later in life with consistent growth. PN grow along nerves and involve multiple nerve branches and can cause significant morbidity owing to compressed vital structures, pain, disfigurement, and the risk of malignant transformation (Fig. 4). Surgery has been suggested as the only standard treatment for PN. However, up to $44 \%$ of tumors progress after the first surgery, especially in patients aged $<10$ years with head and neck tumors that are not completely resectable. ${ }^{21,23)}$

\section{Management and selumetinib}

The treatment of NF1 is mostly supportive and conservative. However, patients with clinical features of severe phenotypes

Table 2. Mechanism of action and results of the clinical trials with targeted agents for the treatment of progressive plexiform neurofibromas

\begin{tabular}{|c|c|c|}
\hline Drug & Mechanism of action & Results \\
\hline Tipifarnib & $\begin{array}{l}\text { Farnesyltransferase inhibitor } \\
\text { - Prevent RAS from binding to the } \\
\text { membrane }\end{array}$ & $\begin{array}{l}\text { Patient: } 31 \text { patients (median age, } 9.7 \text { years; range, } 3-21.5 \text { years) treated with tipifarnib, } \\
29 \text { patients treated with placebo (median age, } 8.2 \text { years; range, } 3-17.7 \text { years) } \\
\text { Treatment: Tipifarnib/placebo administered orally } 200 \mathrm{mg} / \mathrm{m}^{2} / \text { dose after a meal every } \\
12 \text { hours for } 21 \text { days followed by a } 7 \text {-day rest period for } 28 \text {-day treatment cycles } \\
\text { Result: The median TTP was } 10.6 \text { months on the placebo arm and } 19.2 \text { months on the } \\
\text { tipifarnib arm }(P=0.12 ; 1 \text {-sided). }\end{array}$ \\
\hline Pirfenidone & $\begin{array}{l}\text { 5methyl-1-phenyl-2-(1H)-pyri- } \\
\text { done } \\
\text { - Modulates the expression of } \\
\text { growth factors and cytokines } \\
\text { that are relevant to fibrosis }\end{array}$ & $\begin{array}{l}\text { Patient: } 36 \text { patients (median age, } 8.9 \text { years; range, } 3-18.8 \text { years), placebo arm from the } \\
\text { tipifarnib trial } \\
\text { Treatment: } 500 \mathrm{mg} / \mathrm{m}^{2} / \text { dose every } 8 \text { hours on a continuous dosing schedule for } 28 \text {-day } \\
\text { treatment cycles } \\
\text { Result: The median TTP for pirfenidone was } 13.2 \text { months compared to } 10.6 \text { months for } \\
\text { the placebo control group ( } 2 \text {-tailed } P=0.92 ; 1 \text {-tailed } P=0.46 \text { ) }\end{array}$ \\
\hline Sirolimus & $\begin{array}{l}\text { Mammalian target of rapamycin } \\
\text { (mTOR) inhibitor } \\
\text { - Neurofibromin controls cell growth } \\
\text { by negatively regulating mTOR } \\
\text { pathway activity }\end{array}$ & $\begin{array}{l}\text { Patient: } 29 \text { patients treated with sirolimus (median age, } 8.2 \text { years; range, } 3-17.7 \text { years), } \\
46 \text { patients treated with placebo (median age, } 7.9 \text { years; range, } 3-45.4 \text { years) } \\
\text { Treatment: Starting dose of sirolimus was } 0.8 \mathrm{mg} / \mathrm{m}^{2} \text { body-surface area by mouth twice } \\
\text { daily for a } 28 \text {-day course, achieve a trough blood concentration of } 10-15 \mathrm{ng} / \mathrm{mL} \\
\text { Result: The estimated median TPP of subjects receiving sirolimus was } 15.4 \text { months ( } 95 \% \\
\text { Cl, } 14.3-23.7 \text {, which was significantly longer than } 11.9 \text { months }(P<0.001) \text {, the median } \\
\text { TTP of the placebo }\end{array}$ \\
\hline $\begin{array}{l}\text { Pegylated } \\
\text { interferon } \\
a-2 b\end{array}$ & $\begin{array}{l}\text { Type } 1 \text { interferons } \\
\text { - have antiproliferative, antiviral, } \\
\text { immunoregulatory, and antitumor } \\
\text { activities }\end{array}$ & $\begin{array}{l}\text { Patient: } 82 \text { patients (median age, } 10 \text { years; range, } 1.6-21.4 \text { years) } \\
\text { Treatment: Weekly subcutaneous injection at a dose of } 1.0 \mu \mathrm{g} / \mathrm{kg} / \mathrm{wk} \\
\text { Result: Imaging responses ( } \geq 20 \% \text { decrease in volume) in } 4 \text { patients }(5 \%)\end{array}$ \\
\hline Imatinib & $\begin{array}{l}\text { Tyrosine kinase inhibitor } \\
\text { - targeting cellular phospho- } \\
\text { signaling cascades in the tumor } \\
\text { microenvironment }\end{array}$ & $\begin{array}{l}\text { Patients: } 36 \text { patients (median age, } 13 \text { years; interquartile range, } 7.5-23 \text { years) } \\
\text { Treatment: Daily oral imatinib mesylate at } 220 \mathrm{mg} / \mathrm{m}^{2} \text { twice a day for children and } 400 \\
\text { mg twice a day for adults for } 6 \text { months } \\
\text { Results: Six of } 36 \text { patients ( } 17 \% \text { ) with a } 20 \% \text { or more decrease in tumor volume. }\end{array}$ \\
\hline Selumetinib & $\begin{array}{l}\text { Selective mitogen-activated pro- } \\
\text { tein kinase kinase inhibitor } \\
\text { - targeted inhibition of RAS path- } \\
\text { way }\end{array}$ & $\begin{array}{l}\text { Patients: } 24 \text { patients (median age, } 10.9 \text { years; range, } 3.0-18.5 \text { years) } \\
\text { Treatment: Selumetinib was administered twice daily at a dose of } 20 \text { to } 30 \mathrm{mg} \text { per } \\
\text { square meter of body-surface area on a continuous dosing schedule (in } 28 \text {-day cycles) } \\
\text { Result: Partial responses (tumor volume decreases from baseline of } \geq 20 \% \text { ) in } 17 \text { of the } \\
24 \text { children ( } 71 \%)\end{array}$ \\
\hline
\end{tabular}

TPP, time to progression; $\mathrm{Cl}$, confidence interval. 
$\left(\mathrm{NF}^{+}\right)^{3)}$ require referral to an appropriate center that can provide genetic analysis, evaluate multiorgan involvement, and surgical treatment. Cutaneous neurofibromas can be surgically removed if they are continuously growing, causing pain or disfigurement, or patients elect to have them removed.

Regular neuropsychological assessment is needed. Wholebody magnetic resonance imaging is an efficient method of detecting brain, optic nerve, and vascular abnormalities as well as internal neurofibromas and other tumors.

Regular ophthalmological assessment is also recommended to survey the functional abnormalities associated with optic pathway glioma. Progressive optic pathway gliomas with visual impairment require chemotherapy, but the outcomes are controversial. ${ }^{18)}$ Vascular abnormalities should be treated according to the neurological or neurosurgical assessment findings.

Surgical treatment should be considered for symptomatic moyamoya disease associated with NF1 and severe scoliosis, but the outcomes of surgery for tibial pseudarthrosis remain unsatisfactory and the procedure is challenging. ${ }^{30)}$

$\mathrm{PN}$ is a devastating complication of NF1. Progressively growing PN must be removed because of its potential for malignant transformation. However, complete resection is impossible in a substantial number of patients. ${ }^{21,23)}$ Much effort has been directed to clinical trials with targeted agents ${ }^{31)}$ such as tipifarnib, ${ }^{32)}$ pirfenidone, ${ }^{33)}$ sirolimus, ${ }^{34)}$ pegylated interferon $\alpha-2 b,{ }^{35)}$ and imatinib $^{36)}$ (Table 2). Among these trials, a decrease in the tumor volume $\geq 20 \%$ from baseline was identified in only 4 of 83 patients (5\%) in the pegylated interferon alfa- $2 \mathrm{~b}$ trial ${ }^{35)}$ and in only 6 of $36(17 \%)$ in the imatinib trial. ${ }^{36}$

NF1 is caused by a germline loss of function of the NF1 gene at 17q11.2. The NF1 gene encodes neurofibromin, a tumor suppressor that regulates Ras activity via the hydrolysis of RASGTP to RAS-GDP. ${ }^{37)}$ Loss of NF1 heterozygosity is associated with the development of PN in neoplastic Schwann cells. ${ }^{23,38)}$

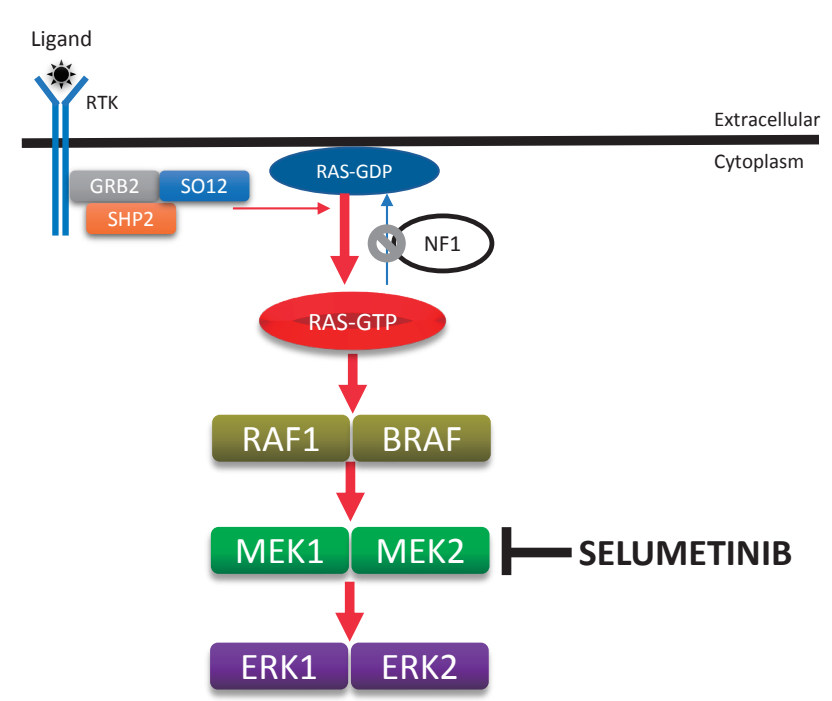

Fig. 5. Enhanced activity of the RAS-MAPK signaling pathway due to the loss-of-function mutation of the NF1 gene and mode of selumetinib action. MAPK, mitogen-activated protein kinase; ERK, extracellularsignal-regulated kinase.
Therefore, loss of neurofibromin is associated with elevated activated Ras levels. Activated RAS increases the activities of RAF, MEK, and ERK, which comprise an important signaling pathway for increased cell growth, proliferation, and differentiation (Fig. 5).

Selumetinib (AZD6244; AstraZeneca plc., Cambridge, UK), an oral selective MEK inhibitor, decreases PN size without serious adverse reactions in pediatric patients. ${ }^{39)}$ A phase II study of selumetinib $\left(25 \mathrm{mg} / \mathrm{m}^{2}\right)$ with a median of 30 cycles (28-day) showed tumor volume decreases from baseline of $\geq 20 \%$ in $71 \%$ of pediatric patients without disease progression as well as decreases from a baseline neurofibroma volume in 12 of 18 mice (67\%). Disease progression ( $\geq 20 \%$ increase in tumor volume from baseline) has not yet been found. Asian patients might have had higher exposure to selumetinib than other populations, and a lower dosage might be safer for Asians than for other populations. However, only one study has investigated selumetinib pharmacokinetics in healthy adult Asians. ${ }^{40)}$ One ongoing clinical study is investigating the clinical safety, pharmacokinetic properties, and effects of selumetinib in Korean patients with NF1 and inoperable PN (https://cris.nih.go.kr/cris/ en/search/search_result_st01.jsp?seq $=13575 ; \quad$ KCT0003700). The U.S. Food and Drug Administration approved selumetinib (Koselugo) for pediatric patients with symptomatic inoperable PN in April 2020, leading to the dawn of a new era in the treatment of NF1. Notably, selumetinib also exerts clinically beneficial effects on pediatric low-grade glioma. ${ }^{41)}$

In conclusion, multisystemic and lifelong surveillance is required for NF1, which is one of the most common genetic diseases. The introduction of new therapeutic agents will improve the quality of life and survival rates of affected patients, provoke further investigations into the usefulness of selumetinib for conditions other than PN, and aid in the development of new therapeutic agents.

\section{Conflicts of interest}

No potential conflict of interest relevant to this article was reported.

\section{Acknowledgments}

This research was supported in part by the Bio \& Medical Technology Development Program of the National Research Foundation (NRF) funded by the Korean government (NRF2018M3A9H1078335).

See the commentary "Improving the lives of children with neurofibromatosis type 1" via https://doi.org/10.3345/cep.2020. 01277.

\section{References}

1. Korf BR. Plexiform neurofibromas. Am J Med Genet 1999;89:31-7.

2. Needle MN, Cnaan A, Dattilo J, Chatten J, Phillips PC, Shochat S, et al. Prognostic signs in the surgical management of plexiform neurofibroma: 
the Children's Hospital of Philadelphia experience, 1974-1994. J Pediatr 1997;131:678-82.

3. Kang E, Kim YM, Seo GH, Oh A, Yoon HM, Ra YS, et al. Phenotype categorization of neurofibromatosis type I and correlation to NF1 mutation types. J Hum Genet 2020;65:79-89.

4. National Institutes of Health Consensus Development Conference Statement: neurofibromatosis. Bethesda, Md., USA, July 13-15, 1987. Neurofibromatosis 1988;1:172-8.

5. DeBella K, Poskitt K, Szudek J, Friedman JM. Use of "unidentified bright objects" on MRI for diagnosis of neurofibromatosis 1 in children. Neurology 2000;54:1646-51.

6. van Minkelen R, van Bever Y, Kromosoeto JN, Withagen-Hermans CJ, Nieuwlaat A, Halley DJ, et al. A clinical and genetic overview of 18 years neurofibromatosis type 1 molecular diagnostics in the Netherlands. Clin Genet 2014;85:318-27.

7. Fahsold R, Hoffmeyer S, Mischung C, Gille C, Ehlers C, Kücükceylan N, et al. Minor lesion mutational spectrum of the entire NF1 gene does not explain its high mutability but points to a functional domain upstream of the GAP-related domain. Am J Hum Genet 2000;66:790-818.

8. Sabbagh A, Pasmant E, Imbard A, Luscan A, Soares M, Blanché H, et al. NF1 molecular characterization and neurofibromatosis type I genotypephenotype correlation: the French experience. Hum Mutat 2013;34: $1510-8$.

9. Valero MC, Martín Y, Hernández-Imaz E, Marina Hernández A, Meleán G, Valero AM, et al. A highly sensitive genetic protocol to detect NF1 mutations. J Mol Diagn 2011;13:113-22.

10. Wimmer K, Yao S, Claes K, Kehrer-Sawatzki H, Tinschert S, De Raedt T, et al. Spectrum of single- and multiexon NF1 copy number changes in a cohort of 1,100 unselected NF1 patients. Genes Chromosomes Cancer 2006;45:265-76.

11. Mautner VF, Kluwe L, Friedrich RE, Roehl AC, Bammert S, Högel J, et al. Clinical characterisation of 29 neurofibromatosis type- 1 patients with molecularly ascertained 1.4 Mb type-1 NF1 deletions. J Med Genet 2010; 47:623-30.

12. Pasmant E, Sabbagh A, Spurlock G, Laurendeau I, Grillo E, Hamel MJ, et al. NF1 microdeletions in neurofibromatosis type 1: from genotype to phenotype. Hum Mutat 2010;31:E1506-18.

13. Upadhyaya M, Huson SM, Davies M, Thomas N, Chuzhanova N, Giovannini S, et al. An absence of cutaneous neurofibromas associated with a 3-bp inframe deletion in exon 17 of the NF1 gene (c.2970-2972 delAAT): evidence of a clinically significant NF1 genotype-phenotype correlation. Am J Hum Genet 2007;80:140-51.

14. Pinna V, Lanari V, Daniele P, Consoli F, Agolini E, Margiotti K, et al. p.Arg1809Cys substitution in neurofibromin is associated with a distinctive NF1 phenotype without neurofibromas. Eur J Hum Genet 2015;23:1068-71.

15. Rojnueangnit K, Xie J, Gomes A, Sharp A, Callens T, Chen Y, et al. High incidence of Noonan syndrome features including short stature and pulmonic stenosis in patients carrying NF1 missense mutations affecting p.Arg1809: genotype-phenotype correlation. Hum Mutat 2015;36:105263.

16. Koczkowska M, Chen Y, Callens T, Gomes A, Sharp A, Johnson S, et al. Genotype-phenotype correlation in NF1: evidence for a more severe phenotype associated with missense mutations affecting NF1 codons 844848. Am J Hum Genet 2018;102:69-87.

17. Ferrari F, Masurel A, Olivier-Faivre L, Vabres P. Juvenile xanthogranuloma and nevus anemicus in the diagnosis of neurofibromatosis type 1. JAMA Dermatol 2014;150:42-6.

18. Friedrich RE, Nuding MA. Optic pathway glioma and cerebral focal abnormal signal intensity in patients with neurofibromatosis type 1 : characteristics, treatment choices and follow-up in 134 affected individuals and a brief review of the literature. Anticancer Res 2016;36:4095-121.

19. Drouet A, Wolkenstein P, Lefaucheur JP, Pinson S, Combemale P, Gherardi RK, et al. Neurofibromatosis 1-associated neuropathies: a reappraisal. Brain 2004;127(Pt 9):1993-2009.

20. Licis AK, Vallorani A, Gao F, Chen C, Lenox J, Yamada KA, et al. Prevalence of sleep disturbances in children with neurofibromatosis type 1.
J Child Neurol 2013;28:1400-5.

21. Dombi E, Solomon J, Gillespie AJ, Fox E, Balis FM, Patronas N, et al. NF1 plexiform neurofibroma growth rate by volumetric MRI: relationship to age and body weight. Neurology 2007;68:643-7.

22. Ragge NK, Falk RE, Cohen WE, Murphree AL. Images of Lisch nodules across the spectrum. Eye (Lond) 1993;7(Pt 1):95-101.

23. Kluwe L, Friedrich RE, Mautner VF. Allelic loss of the NF1 gene in NF1associated plexiform neurofibromas. Cancer Genet Cytogenet 1999; 113:65-9.

24. Maruoka R, Takenouchi T, Torii C, Shimizu A, Misu K, Higasa K, et al. The use of next-generation sequencing in molecular diagnosis of neurofibromatosis type 1: a validation study. Genet Test Mol Biomarkers 2014; 18:722-35

25. Murphy ES, Xie H, Merchant TE, Yu JS, Chao ST, Suh JH. Review of cranial radiotherapy-induced vasculopathy. J Neurooncol 2015;122:4219.

26. Miller DT, Freedenberg D, Schorry E, Ullrich NJ, Viskochil D, Korf BR, et al. Health supervision for children with neurofibromatosis type 1 . Pediatrics 2019;143:e20190660.

27. Lehtonen A, Howie E, Trump D, Huson SM. Behaviour in children with neurofibromatosis type 1: cognition, executive function, attention, emotion, and social competence. Dev Med Child Neurol 2013;55:11125 .

28. Descheemaeker MJ, Plasschaert E, Frijns JP, Legius E. Neuropsychological profile in adults with neurofibromatosis type 1 compared to a control group. J Intellect Disabil Res 2013;57:874-86.

29. Hirbe AC, Gutmann DH. Neurofibromatosis type 1: a multidisciplinary approach to care. Lancet Neurol 2014;13:834-43.

30. Borzunov DY, Chevardin AY, Mitrofanov AI. Management of congenital pseudarthrosis of the tibia with the Ilizarov method in a paediatric population: influence of aetiological factors. Int Orthop 2016;40:331-9.

31. Packer RJ, Gutmann DH, Rubenstein A, Viskochil D, Zimmerman RA, Vezina G, et al. Plexiform neurofibromas in NF1: toward biologic-based therapy. Neurology 2002;58:1461-70.

32. Widemann BC, Dombi E, Gillespie A, Wolters PL, Belasco J, Goldman $\mathrm{S}$, et al. Phase 2 randomized, flexible crossover, double-blinded, placebocontrolled trial of the farnesyltransferase inhibitor tipifarnib in children and young adults with neurofibromatosis type 1 and progressive plexiform neurofibromas. Neuro Oncol 2014;16:707-18.

33. Widemann BC, Babovic-Vuksanovic D, Dombi E, Wolters PL, Goldman S, Martin S, et al. Phase II trial of pirfenidone in children and young adults with neurofibromatosis type 1 and progressive plexiform neurofibromas. Pediatr Blood Cancer 2014;61:1598-602.

34. Weiss B, Widemann BC, Wolters P, Dombi E, Vinks AA, Cantor A, et al. Sirolimus for non-progressive NF1-associated plexiform neurofibromas: an NF clinical trials consortium phase II study. Pediatr Blood Cancer 2014;61:982-6.

35. Jakacki RI, Dombi E, Steinberg SM, Goldman S, Kieran MW, Ullrich NJ, et al. Phase II trial of pegylated interferon alfa- $2 \mathrm{~b}$ in young patients with neurofibromatosis type 1 and unresectable plexiform neurofibromas. Neuro Oncol 2017;19:289-97.

36. Robertson KA, Nalepa G, Yang FC, Bowers DC, Ho CY, Hutchins GD, et al. Imatinib mesylate for plexiform neurofibromas in patients with neurofibromatosis type 1: a phase 2 trial. Lancet Oncol 2012;13:1218-24.

37. Xu GF, O'Connell P, Viskochil D, Cawthon R, Robertson M, Culver M, et al. The neurofibromatosis type 1 gene encodes a protein related to GAP. Cell 1990;62:599-608.

38. Serra E, Rosenbaum T, Winner U, Aledo R, Ars E, Estivill X, et al. Schwann cells harbor the somatic NF1 mutation in neurofibromas: evidence of two different Schwann cell subpopulations. Hum Mol Genet 2000;9:3055-64.

39. Dombi E, Baldwin A, Marcus LJ, Fisher MJ, Weiss B, Kim A, et al. Activity of selumetinib in neurofibromatosis type 1-related plexiform neurofibromas. NEngl J Med 2016;375:2550-60.

40. Dymond AW, Elks C, Martin P, Carlile DJ, Mariani G, Lovick S, et al. Pharmacokinetics and pharmacogenetics of the MEK1/2 inhibitor, selumetinib, in Asian and Western healthy subjects: a pooled analysis. Eur J Clin Pharmacol 2017;73:717-26. 
41. Fangusaro J, Onar-Thomas A, Young Poussaint T, Wu S, Ligon AH, Lindeman N, et al. Selumetinib in paediatric patients with BRAFaberrant or neurofibromatosis type 1-associated recurrent, refractory, or progressive low-grade glioma: a multicentre, phase 2 trial. Lancet Oncol 2019;20:1011-22.
How to cite this article: Kang E, Yoon HM, Lee BH. Neurofibromatosis type I: points to be considered by general pediatricians. Clin Exp Pediatr 2021;64:149-56. https://doi. org/10.3345/cep.2020.00871 